\title{
The Modifications of Spiritual Healing in Bali Tourism
}

\author{
I Gede Sutarya and I Nyoman Sirtha
}

Doctorate Program in Tourism

Universitas Udayana

Corresponding author: sutarya@yahoo.com

\section{ARTICLE INFO}

Received

8 September 2016

Accepted

5 February 2017

Available online 31 March 2017

\begin{abstract}
Spiritual healing is a health development through a kind of spiritual activities like mantra, religious symbols, rituals, breathing, and meditation that have entered into the tourism of Bali. The study reveals the modifications of spiritual healing in Bali tourism. The research was conducted in Ubud Tourism Region and in the Region of Muncan. This study is a qualitative research. The collection of data was conducted through literature study, observation and interviews. The analysis was conducted qualitatively by classification, interpretation and inference. Modification of spiritual healing in Bali tourism occurred as a result of the dialogue among tourists with healers or local gurus.This modification revises and adds spiritual healing, by maintaining the native gurus and the native rituals of Bali. Native gurus and native rituals of Bali are the expectation of the spiritual healing of foreign tourists in Bali. This expectation is manifest in the longing for gurus and the development of authentic atmosphere. Thus, the native gurus and the native Balinese ritual are augmented products in the Bali spiritual healing in the face of competition from similar products. This indicates that Bali must retain its image as the original source of spiritual healing in the world.
\end{abstract}

Keywords: spiritual healing, Bali tourism, native gurus and rituals, augmented products

\section{Introduction}

\section{Background}

The growth of tourism in Bali has led to numerous creative people who have been influenced by the development of tourism. Romanticism of traditional culture is the main attraction of foreign tourists coming to the Asian countries (Smith and Raeper, 2000:117), expanding to search for religious and ethnic traditions cited by Hollinshead (1999) as a secular pilgrimage. The foreign tourists quests also occurred in Bali, through spiritual quest which is the health development efforts of body, mind, and spirit by using such spiritual mantras, rituals, breathing energy, and religious symbols.

http://ojs.unud.ac.id/index.php/eot
Ubud Tourism Region is one area of tourism for development of spiritual healing for tourists. Ubud Tourism Region become places for ashrams, such Munivara Ashram and Ambar Ashram that offer spiritual healing for tourists. Activity centers such as Yoga Barn and Radiantly Alive also growing in Ubud Tourism Region. Star accommodation facilities such as the Four Seasons Sayan, Ubud and Bagus Jati, Ubud also offer facilities for spiritual healing. Muncan of Karangasem region is an area outside the tourism area that develops for Ratu Bagus Ashram as the destination of international tourists to seek of spiritual healing. Developments in Muncan coincides also with the development of of spiritual healing in the surrounding area, such 
as what was done by Cepik Villa in Sidemen (www.cepikvilla.com), of Karangasem, which offers spiritual healing. Businesses of spiritual healing in Karangasem extend to the surrounding areas of Manggis, Candidasa, and Pakse Bali, Klungkung.

The development of spiritual healing business is a new thing in the Bali tourism, which is becoming more popular after the publication of the novel Eat Pray Love in 2006. After the publication of novel Eat Pray Love, the development of spiritual healing has been growing rapidly in Ubud, such as the Yoga Barn and Radiantly Alive since 2006. In fact, the development of spiritual healing began in the 1970s in Bali through the arrivals of foreign tourist of hippies (Picard, 2006:100) who brought along yoga gurus to Bali because of the hippies interest of the mystical world from the East (Vickers, 1989 : 187).

The tourists' quests for spiritual healing is a form of search for spiritual ethnic lifestyle, as happens in the case of foreign tourists' quests of Sangoma Ritual in Africa (Binsbergen, 1999) and the Ritual of Ayahuascha in the Amazon, South America (Winkelman, 2005). In the studies on tourism, the tourists' quests of ethnic life style are related to the searches of uniqueness. The uniqueness is associated with authenticity which is the deepest values of uniqueness (Apostolokis, 2003: 802). However, in the development of tourism, the values of authenticity have continuously undergone changes.

Such modifications, for example, found in the ashrams in India. On research conducted in Vrindavan, India (Carney, 2007:142), ashrams in Vrindavan developed ashrams with luxurious facilities called condo-ashram. Smith and Puczkó (2010:167) stated that the Asian healing such as Shambala Healing, Buddhist Spirituality, and Yoga has evolved in the modern resorts in the UK. Lalonde (2012) also states that Asanas have been growing at luxury villa facilities, star hotels, and luxury tourism facilities in Peru and Canada.

The spiritual healing business development in the tourism industry has brought many modifications in spiritual healing. For example in India, the simple life

http://ojs.unud.ac.id/index.php/eot of ashram has been transformed into a luxurious ashram life, so it changed the simple life experience. In the examples found in Peru and Canada, the activities of yoga are performed in a place close to the out doors that converted to villas and luxury hotels. These modifications give rise to differences in the experiences of tourists, but it is made as if it were a real or authentic experience.

Therefore, there is a gap between the expectations of tourists and the authenticity as well as the development of spiritual healing in Bali, which continues to undergo modification. This gap is the research problem with the formulation of the problems: the spiritual healing modifications in the Bali tourism, the tourists' experiences on the spiritual healing modification, and the most important elements of spiritual healing as the main attraction of tourists.

\section{Research Objective}

The objective of this study is to explore the modifications of spiritual healing in Bali Tourism. This study aimed to analyze the modifications of spiritual healing in Bali tourism, to formulate the foreign tourists' experiences on spiritual healing in Bali, and to analyze the most important elements of spiritual healing in Bali as the main attraction of tourists. The research analysis modification of spiritual healing used the Products Planning Theory.

\section{Methodology}

This research was conducted in the Tourism Area of Ubud, Gianyar and Muncan region of Karangasem. The Tourism Area of Ubud as the representative of the region that has a rapid development of spiritual healing businesses while the Muncan area as the representatives from those outside the tourist area of which development of spiritual healing began to grow. The research was conducted from August 2014 to April 2016. It is a qualitative research and the data collection was conducted by literature study, observations and interviews. Observations were carried out at Munivara Ashram, Ambar Ashram, Ratu Bagus Ashram, Yoga Barn, Radiantly Alive, Ni Wayan Nuriasih Practice, Nyoman LatraPractice (son of the late Ketut 
Liyer), Four Seasons Sayan, Ubud, and BagusJati, Ubud. In-Depth interviews were conducted with seven foreign tourists, 10 businesses of spiritual healing, and five policy makers. The data collections were analyzed qualitatively through classification, interpretation, and inference.

\section{Results and Discussion}

\section{Spiritual Healing Development}

The quests for spiritual healing to Bali from the Europeans have started since the 1920s. The quests resulted in the translation in Dutch of Lontar Usada Sari pertaining tothe Balinese spiritual healingin 1923. The translation was conducted by Kleiweg and Lekkerker, (1927: 239) found Tampak Siring, Gianyar as a destination for spiritual healing in Bali, but (Hobart, 2003: 1) argued that the Balinese spiritual healing was first introduced to Europe in the 1930s. The interest on the spiritual healing in the early days of tourism in Bali was less than the interest of the Europeans to the magical stories of Bali, such as the story of Leak (Powel, 1987: 235). Therefore, the tourists' early questswere mainly the hunts for Leak, however, in the 1970s, hippies tourists who embraced the spiritual freedom came to Bali. They brought along spiritual teachers to practice yoga and meditation in Bali.

Hence, the development of spiritual healing in Bali has been the influence of modern spiritual movements in the world combined with the local Balinese spiritual healing. The potential of spiritual healing in Bali such as the Balian Usada, Balian Kapica, Balian Katakson, BalianTenung, and those Balian with special expertise (Nala, 2006) thrive in the world of tourism after getting the influence of modern spiritual movements, like yoga and meditation mainly carried out by hippies in Bali.Thus, the hippies' activities have been the inspiration for the local spiritual gurus like I Ketut Arsana who become a yoga guru for foreign tourists.

Arsana started doing spiritual healing for foreign tourists in 1981 by establishing the Body Work and Meditation at his private house, Jalan Hanoman 25, Ubud. Arsana who masters the Usada Buda Kecapi made the combination of Yoga, Tantra and Meditation to establish his spiritual healing business. Guru Made Sumantra also took the opportunity of spiritual healing in the 1980 s by combining malukat or spiritual purification with yoga, developed for tourists in 1995. Ratu Bagus, who incidentally visited by tourists from Italy in 1993 also performed the Bayu Suci combination with modern knowledge. This combination was developed as Shaking since 1994. Therefore, from 1990s to 2000s, spiritual healing began to grow into the tourism business.

Entering the 2000s, the spiritual healing grew rapidly. I Made Gunarta, owner of Yoga Barn started to prepare a ware house in his private home as a place to practice Yoga in 2003. I Made Suambara, the owner of Ambar Ashram started to train tourists at his private home in 2001. Ni Wayan Nuriasih started up a spiritual healing practice for foreign tourists in 2002. A manager of a Travel Agent, Miyadi Wiharja confirmed that spiritual healing began to grow rapidly since 2005 in Bali. spiritual healing rapidly increasing growth was in conjunction with the publication of novel Eat Pray Love in 2006, with the establishments of the professional businesses in the field of spiritual healing, such as the Yoga Barn and Radiantly Alive in Ubud, Gianyar.

The data show that from 1970 to 1980 , Bali became the place for spiritual healing practice with teachers or gurus brought from abroad by the tourists. In the years between 1980 and 1990, the local people started to engage in the businesses of spiritual healing. In the years from 1990 to 2000 , the local people (the Balinese) started exploring the spiritual healing in Bali for tourists. From 2000 to 2016, it grew very rapidly characterized by the evolving growth of spiritual healing services in Ubud. For example, Arsana expanded his business by building Omham Retreat Hotel in Junjungan, Ubud in 2014 and RatuBagus Ashram continues to develop its facilities between the years 2000 to 2016 .

\section{Modifications of Spiritual Healing}

The development of spiritual healing in Bali tourism was preceded by dialogues between the tourists and the local teachers 
(gurus). Ratu Bagus developed Shaking based on his dialogues with tourists from Italy in 1993. Suambara developed the Laugh Yoga after having a dialogue with a German tourist, Ully in the 1990s. Nuriasih began practicing spiritual healing business after having cooperation with an Australian tourist, Margareth in 2002. Thus, it can be concluded that there is interference by foreign tourists in the development of tourism products of spiritual healing in Bali.

"At first I collaborated with Margareth, then collaborated with the Germans, but then split up because they wanted to pursue a different business. I then started the businesson my own "(Nuriasih, interview, January 28, 2016).

Other healers, such as Ketut Liyer, Arsana and Sumantra make communication with tourists through the association and books. Liyer practiced after combining the Balinese prophecies by practicing palmistry readings commonly known in the world. Arsana became a yoga teacher influenced by his formal school or education background of Hinduism that originally gained a touch of Indians named Narendra Pandit Sastri (Sutarya, 2015). Sumantra became a healer for tourists after observing the activities of foreign tourists in Ubud. Hence, the development of spiritual healing product in Bali has been the results of the dialogues between the local teachers and the tourists done directly and indirectly.

The dialogues were directly done by preparing products jointly as it was done by Nuriasih, Ratu Bagus and Suambara. Indirect dialogues were done by observation and learning with foreigners, as carried out by Arsana, Sumantra, and Liyer. The dialogues directly and indirectly have resulted in modifications to the spiritual healing in Bali. Nuriasih added with her herbal knowledge, Ratu Bagus added the modern presentation of examples of teaching machines and gayatri mantra of Indian style, Suambara equipped Yoga with modern dance of India, Arsana modified tantra with yoga, Sumantra equipped Bali Yoga with knowledge of modern yoga, as well as Liyer added his palmistry readings with modern astrology.
The dialogues with these tourists directly and indirectly modify various forms of spiritual healing in Bali. Asana is modified into gymnastics, Pranayama into breathing for health, Dhyana into meditation, Tantra into holistic healing, Usada into Balinese Holistic Healing, Tenung into Balinese Astrology, BayuSuci into Shaking, and Malukat into Bathing Ritual. This modification is not merely the name changes but also the form changes. Of these form changes, some elements are taken from outside Bali, to complete their spiritual healing services.

Ratu Bagus Ashram as an example of modifying the Bayu Suci into Shaking. This modification changed the explanation of Shaking using a machine and adding Gayatri style of India into Shaking. "Gayatri Indian style that was common for tourists" (Ratu Bagus, interview, March 1, 2016). Arsana is another example of modifying the tantra into holistic healing, combining yoga, massage, and herbal medicines.Nuriasih modified Usada into Balinese Holistic Healing by combining Balinese traditional medicine with herbal knowledge. Suambara modified Yoga by adding modern Indian dances to evoke the excitement of foreign tourists. The Four Seasons Sayan modified malukat, the bathing ritual by combining it with breathing and asanas.

Of the modification of spiritual healing, two important things that have never been omitted namely the native gurus and the native rituals of Bali. Modifications in Ratu Bagus Ashram, still prioritize Ratu Bagus as the guru and perform Balinese ritual in the ashram namely giving Tirta (holy water) and Bija (rice that has been blessed). Modifications in Munivara Ashram make Arsana as the native guru and the native Balinese ritual on every Kliwon day (name of the day in the Balinese tradition).Nuriasih in the modification also continue to focus on her as the native guru and to make a typical native Balinese rice ritual of Wong-Wongan .Liyer also continued to rely on himself and his son, Nyoman Latra as the native guru and also conduct ritual of malukat for tourists who are willing to do so.

The native Balinese guru and rituals are two important things that have never been eliminated in the modification of spiritual 
healing in Bali. The presence of native Balinese guru is related to the expectations of tourists coming to Bali. Talei Barber (53 Years), an Australian tourist said that he has been doing yoga since he was living in his country, but he wanted to practice it in Bali and to meet with the native Hindu guru of yoga. Gudbjorg (51 years old), a tourist from Iceland also expressed the desire to meet with the native Balinese guru. "He (Arsana) has charisma, I think he got charisma from his original knowledge so I come to Bali because I want to meet Bali Yoga instructor" (Barber, 14 November 2015).

Ritual is generating spiritual atmosphere in the ashram life, so that tourists feel the difference from everyday events compared to the ashram life. It is perceived by Arthurmari (33 years old) a tourist from Belgium after spending two weeks in RatuBagus Ashram by following Shaking and its rituals. "There are big changing in my life after I stay in the ashram" (Arthurmari, interviews, August 3, 2014). Anahita (55 Years) a tourist from Spain said "many changing in my life after Shaking and retreat here" (interview, August 3, 2014).

The self-changes were also perceived by Brittanny Skusek (25-30 years old), a Canadian tourist and Shanta (55-60 years old), a tourist from the Netherlands. They felt a different atmosphere in the ashram which made changes in themselves, from a less healthy life physically and spiritually into a healthy life both physically and spiritually. These changes made their condition became better after staying at the ashram. "Everybody is happy here, so I felt spirituality and culture around me" (Britanny, interview, July 29, 2015).

The tourists experiences indicate that the native Balinese gurus and self-changes become the expectations of tourists. The foreign tourists' expectations are fulfilled by maintaining the native Balinese guru and the Balinese rituals in the modification process. Therefore, the search for the authenticity of spiritual healing by the foreign tourists in Bali end as they find the native guru and the native rituals of Bali. The native gurus and rituals have been satisfying the desire of tourists to the native gurus and the original atmosphere of a growing spiritual healing.

http://ojs.unud.ac.id/index.php/eot
A Yoga teacher, I Ketut Bandiastra (42 years old) justified the expectations of tourists to the native teachers and authentic atmosphere of the birthplace of yoga or spiritual healing in general. The foreign tourists have spiritual centers of luxury in their home country, such as in Australia, but it is not making them satisfied before meeting with gurus from Bali or India. Currently the world yoga centers are in Canada and Australia. Two of these countries have complete training centers. The teachers have also been certified internationally with adequate modern knowledge, but the tourists still come to Bali and India. What are they really looking for? That is, if they meet with teachers from Bali, they feel like to meet with the native gurus (Bandiastra, interview, February 3, 2016).

The need satisfaction of foreign tourists in Bali towards spiritual healing is in line with the statement of Cohen (in Hall, 2003: 287) that the authenticity can be identified through the perception of tourists and what is provided by the host. More explicitly, Apostolakis, (2003:801) says, authenticity is a negotiation between the experience of tourists and the travel objects supplied by the host. If both parties (tourists and host) agree on something as authenticity then it can be called authentic. In the context of spiritual healing quests in Bali, tourists' expectations are to meet the native gurus and the original atmosphere. The host provides the native gurus and the native rituals to meet the yearning and the development of an atmosphere of authenticity.

The experience of meeting the native gurus and performing the native Balinese rituals is a differentiation accordig to the Products Planning Theory. Products Planning Theory mentions four things that must be considered in planning the development of the product, namely identifying specific needs, target markets, self-positioning, and a competitive product (Seaton and Bennett, 1996: 115). The special needs of tourists who are looking for spiritual healing in Bali are the desire to meet the native gurus and the authentic atmosphere of Bali. The target market is tourists who have known spiritual healing in their home countries. Thus, Bali needs to position itself as the original source of spiritual healing that the spiritual healing products in Bali become a competitive 
product.In the attempt to position itself as the original source, Bali has the local teachers and special rituals as the differentiation from other products in the world, so that the local native teachers and these rituals can be referred to as augmented products of spiritual healing in Bali. Augmented products have become a differentiation from similar products in other places in the world.

Augmented products of spiritual healing in Bali are different from those found in India that rely on the gurus and ashrams as the original source of spiritual healing. Bali in competition with India has unique Balinese ritual establishes the mood of authenticity. Thailand (Schedneck, 2014) has a spiritual education and native teachers, but the rituals are different from Bali. Therefore, teachers and rituals become a product differentiation of spiritual healing in Bali with a similar product in other countries. The teachers/gurus and the rituals are something born from ethnic and culture, therefore the augmented products of spiritual healing in Bali belong to the ethnicity and culture of Bali.

Based on the discussion, spiritual healing products can be built through three levels of tourism product development (Seaton and Bennett, 1996) with the cores of health and peace, tangible product in the form of ashram, the practice site, and the healers as well as the augmented products namely ethnic and culture. Ethnicity and culture are the differentiations from a variety of similar products around the world. Resources-based product development in the destination is the criticism against mass tourism in order to build products acceptable to the local communities (Cooper, 2012: 101).The local resources based products are also the parts of the development of sustainable tourism in achieving social and economic goals of tourism development (Hall, 2003: 425).

\section{Conclusion}

The development of spiritual healing in the tourism of Bali has modified the form of spiritual healing in Bali, adding modern knowledge and methods that have been generally accepted throughout the world. These modifications retain the native gurus and the native rituals of Bali as the attraction

http://ojs.unud.ac.id/index.php/eot of foreign tourists. This is done to meet the expectations of tourists towards the authentic experience. This modification is not perceived by foreign tourists because their expectations have been met through the encounters with the native teachers and the authentic atmosphere of the Balinese rituals. Therefore, the native teachers and the native rituals are the attraction for tourists.

The native Balinese teachers and the rituals are born out of ethnicity and culture, because the native teacher is a factor of ethnicity and ritual is the cultural factor. Ethnic and cultural factors are augmented products of spiritual healing in Bali, which distinguishes it from spiritual healing in other countries. Therefore, ethnicity and culture should be maintained in building spiritual healing products in Bali so that it has the product competitiveness with similar products around the world. The development of products based on ethnic and cultural development of the product is based on the local resources which are the basis for sustainable tourism development.

\section{Acknowledgment}

I would like to extend my deepest gratitude to Prof. Dr. I Nyoman Darma Putra, M.Litt as Co-promotor who already shared his experiences in enriching this research

\section{References}

Apostolakis, A. (2003) 'The convergence process in heritage tourism', Annals of tourism research. Elsevier, 30(4), pp. 795-812.

Binsbergen, W. V (1999) 'We are in this for the money', in International Conference Commodification and Identities. Amsterdam.

Carney, G. T. (2007) 'From Ashram to Condo', Southeasth Review of Asian Studies, 29, p. 137-156.

Cohen, E. and Cohen, S. A. (2012) 'Authentication: Hot and cool', Annals of Tourism Research. Elsevier, 39(3), pp. 1295-1314. 
Cooper, C. (2012) Essentials Of Tourism. England: Pearson.

Hall, C. M. (2003) Introduction to Tourism: Dimensions and Issues. Australia: Hospitality Press.

Hobart, A. (2003) Healing Performances of Bali Between Darkness and Light. New York: Berghahn Books Oxford.

Hollinshead, K. (1999) 'Tourism as public culture: Horne's ideological commentary on the legerdemain of tourism', The International Journal of Tourism Research. Wiley Periodicals Inc., 1(4), p. 267.

Kleiweg, J. P. and Lekkerker, C. (1927) De Oesada Sari, Een Balineesch Genesskundig Handschrift. Amsterdam: JH De Bussy.

Lalonde, A. M. G. (2012) Embodying asana in All New Places: Transformational Ethics, Yoga Tourism and Sensual Awakening (Dissertation). University of Victoria.

Nala, N. (2006) Aksara Bali dalam Usada. Surabaya: Paramita.

Picard, M. (2006) Bali: Pariwisata Budaya, Budaya Pariwisata. Jakarta: KepustakaanPopulerGramedia.

Powel, H. (1987) The Last Paradise An American's 'Discovery' of Bali in the 1920's. New York: Singapore Oxford University Press.

Schedneck, B. (2014) 'Meditation for tourists in Thailand: Commodifying a universal and national symbol', Journal of Contemporary Religion. Taylor \& Francis, 29(3), pp. 439-456.

Seaton, A. V and Bennett, M. M. (1996) Marketing Tourism Products; Concepts, Issues, Cases. London: Thomson Business Press.

Smith, L. and Raeper, W. (2000) Ide-ide Filsafat dan Agama Dulu dan Sekarang. Yogyakarta: Kanisius.

http://ojs.unud.ac.id/index.php/eot
Smith, M. and Puczkó, L. (2010) 'Taking your life into your own hands? New trends in European health tourism', Tourism Recreation Research. Taylor \& Francis, 35(2), pp. 161-172.

Sutarya, I. G. (2015) I Nyoman Singgin: Rakawi, Politisi dan Agamawan. Denpasar: Media Bali Online.

Winkelman, M. (2005) 'Drug tourism or spiritual healing? Ayahuasca seekers in Amazonia', Journal of psychoactive drugs. Taylor \& Francis, 37(2), pp. 209-218. 